\title{
Efektifitas Massage Perineum untuk Percepatan Persalinan Kala II pada Ibu Bersalin
}

\author{
Isofi Laspiriyanti ${ }^{1}$, Lina Puspitasari ${ }^{2}$ \\ Email: sofiriyanti57@yahoo.com \\ Akademi Kebidanan Graha Mandiri Cilacap \\ Jalan Dr. Soetomo No.4B Telp (0282) 534908
}

\begin{abstract}
Abstrak
Latar Belakang Penelitian: Perineum kaku disebabkan karena pada syaraf otot perineum terdapat asam piruvat yang masuk ke dalam mitokondria yang diubah menjadi asam laktat. Asam laktat menyebabkan masalah metabolisme dan terjadi penyusutan antar sel otot perineum, sehingga perineum menjadi kaku. Dampak dari perineum kaku dapat menghambat persalinan kala II yang meningkatkan resiko kematian pada janin dan menyebabkan kerusakan-kerusakan jalan lahir atau laserasi. Tujuan Penelitian: untuk terjadi proses percepatan persalinan kala II. Metode Penelitian: Desain penelitian ini menggunakan metode Studi Kasus. Metode sampling yang digunakan adalah non probability sampling melalui pendekatan purposive sampling yang berjumlah 3 pasien. Pasien yang di gunakan sebagai partisipan yaitu pasien ibu bersalin di RSUD Cilacap. Pengambilan data dilakukan pada tanggal 2 Januari sampai 25 Januari 2019. Setelah ditabulasi dengan data yang telah dianalisis dengan menggunakan analisis penjelasan dan deret waktu. Hasil Penelitian: penelitian menunjukan Asuhan Kebidanan Massage Perineum untuk Percepatan Persalinan Kala II Pada Ibu Bersalin. Dengan hasil pada partisipan yang pertama proses percepatan persalinan berlangsung dalam waktu 15 menit. Pada partisipan dua proses percepatan persalinan berlangsung dalam waktu 10 menit. Dan pada partisipan ketiga proses percepatan persalinan berlangsung dalam waktu 20 menit. Kesimpulan: Dengan demikian, bahwa Asuhan Massage Perineum untuk Percepatan Persalinan Kala II Pada Ibu bersalin efektif.
\end{abstract}

Kata Kunci : Perineum, Kaku, Percepatan, Kala II, Massage.

\begin{abstract}
Background: Stiff perineum is caused by the nerves of the perineal muscle contain pyruvic acid which enters the mitochondria which are converted into lactic acid. Lactic acid causes metabolic problems and shrinks between the perineal muscle cells, so the perineum becomes stiff. The impact of a stiff perineum can inhibit the second stage of labor which increases the risk of death to the fetus and causes damage to the birth canal or laceration. Research Objectives: to accelerate the second stage of labor. Research Method: The design of this study uses the case study method. The sampling method used was non probability sampling through a purposive sampling approach of 3 patients. Patients used as participants were maternity patients in Cilacap District Hospital. Data was collected from January 2 to January 25, 2019. After tabulation with data that has been analyzed using analysis of explanation and time series. Results: The study showed there was a great impact of the Perineum Massage Midwifery Care for the Acceleration of Second Stage of Labor in Maternity Women. With the results of the first participant the process of accelerating labor took place within 15 minutes. In the second participant, the process of labor acceleration took place within 10 minutes. And in the third participant the process of accelerating labor took place within 20 minutes. Conclusion: Thus, that Perineum Massage Care for the Acceleration of Second Stage of Labor is really effective.
\end{abstract}

Keywords : Perineum, Stiff, Acceleration, Second Stage, Massage.

\section{Pendahuluan}

Persalinan merupakan proses dimana bayi, plasenta dan selaput ketuban keluar dari uterus ibu. ${ }^{[1]}$

Persalinan dianggap normal jika
prosesnya terjadi pada usia
kehamilan cukup bulan (setelah 37
minggu) tanpa disertai adanya
penyulit. Proses ini berawal dari


pembukaan dan dilatasi serviks sebagai akibat kontraksi uterus dengan frekuensi, durasi, dan kekuatan yang teratur. Mula-mula kekuatan yanng muncul kecil, kemudian terus meningkat sampai pada puncaknya pembukaan serviks lengkap sehingga siap untuk pengeluaran janin dari rahim ibu. . ${ }^{[1]}$ [2]

Menurut Sumarah (2009), tahapan persalinan terdiri dari empat tahap yaitu kala I, kala II, kala III dan kala IV. Kala I berlangsung kurang lebih 18-24 jam, yang terdiri dari fase laten yang berlangsung selama 8 jam, dan fase aktif berlangsung selama 7 jam, yang dibagi dalam 3 fase yaitu fase akselerasi lamanya 2 jam, fase dilatasi lamanya 2 jam dan fase deselerasi lamanya 2 jam. Kala II biasanya berlangsung selama 2 jam pada primi dan 1 jam pada multi. Kala III dimulai segera setelah bayi lahir sampai lahirnya plasenta, yang berlangsung tidak lebih dari 30 menit. Kala IV dimulainya dari saat lahirnya plasenta sampai 2 jam pertama post partum. ${ }^{[3]}$

Kala II lama memiliki dampak yang dapat menimbulkan konsekuensi serius bagi salah satu atau keduanya sekaligus. Dampak persalinan kala II lama yang terjadi pada ibu antara lain yaitu kenaikan insiden atonia uteri, laserasi, perdarahan, infeksi, kelelahan ibu dan shock. Dan sedangkan pada bayi akan mengalami asfiksia, trauma cerebi, cedera, dan infeksi. ${ }^{[4]}$

Menurut data yang di dapat dari profil Kesehatan Provinsi Jawa Tengah (2016), kejadian kematian ibu bersalin pada waktu persalinan sebesar $13,95 \%$ per 100.000 kelahiran hidup. Sedangkan, menurut data Dinkes Kabupaten Cilacap (2016), jumlah AKI sebanyak 25 kasus dengan penyebab diantaranya, perdarahan $28 \%$, preeklampsi $20 \%$, partus lama (macet) 5\% dan penyebab lain $47 \%$. Angka kejadian ini berpengaruh terhadap kondisi kesehatan ibu di Kabupaten Cilacap. Dengan demikian, tidak semua proses persalinan berjalan dengan normal, dalam maksud lama persalinan dan metode persalinan sesuai dengan yang diharapkan. ${ }^{[5]}$

Penyebab kala II lama di pengaruhi oleh faktor-faktor diantaranya yaitu salah satunya Passage (faktor jalan lahir) kelainan dalam ukuran atau bentuk jalan lahir, menyebabkan kemacetan persalinan karena besarnya kepala janin tidak sesuai dengan luasnya panggul atau jalan lahir ibu. Selain itu penyebab dari persalinan yang berlangsung lama adalah kelainan letak janin, kelainan panggul, janin besar, kelainan congenital, kelainan his yang dapat menghambat kelancaran persalinan serta primi tua. ${ }^{[6]}$

Berdasarkan penelitian terdahulu untuk mengetahui lama kala II pada ibu bersalin dengan posisi miring yang pernah dilakukan oleh Indrasari (2014) hasil penelitian menunjukan bahwa ditemukan ratarata lama kala II pada ibu bersalin dengan posisi miring dalam percepatan kala II, dilakukan teknik persalinan pada multi rata-rata waktu yang dibutuhkan dengan posisi miring pada ibu multi adalah 26,02 menit. Ini menunjukkan bahwa posisi miring membuat ibu merasa lebih nyaman dan kontraksi uterus lebih efektif sehingga memudahkan ibu untuk mengedan. Posisi miring dapat digunakan sepanjang kala I dan kala II dengan cara ibu berbaring miring, kedua pinggul dan lutut dalam keadaan fleksi dan diantara kakinya ditempatkan sebuah bantal atau kaki atasnya di angkat dan di sokong. ${ }^{[7]}$

Menurut Bahiyatun (2013), salah satu upaya pencegahan terjadinya persalinan kala II lama adalah dengan melaksanakan proses pimpinan persalinan secara efektif sehingga dapat memanfaatkan his secara optimal dengan proses dorongan melalui tenaga meneran dari ibu bersalin atau dorongan 
Jurnal Kebidanan Harapan Ibu Pekalongan

manual dari tenaga bidan itu sendiri. Salah satu teknik untuk mencegah persalinan kala II lama adalah dengan cara memberi asuhan pada bagian perineum yaitu dengan massage perineum. ${ }^{[8]}$

Dapat disimpulkan bahwa, manfaat massage perineum yaitu meningkatkan aliran darah, melunakkan jaringan di sekitar perineum ibu, sehingga membuat elastis semua otot yang berkaitan dengan proses persalinan termasuk kulit vagina. Saat semua otot-otot menjadi elastis, ibu tidak perlu mengejan terlalu keras cukup pelanpelan saja bahkan bila prosesnya lancar robekan pada perineum tidak terjadi dan vagina tidak perlu dijahit. [9]

Dari berbagai sumber yang sudah di jelaskan sebelumnya, maka peneliti tertarik untuk melakukan penelitian tentang Efektifitas Massage Perineum untuk Percepatan Persalinan Kala II pada Ibu Bersalin.

\section{Metode Penelitian}

Desain penelitian ini menggunakan strategi penelitian kualitatif dengan strategi penelitian case study research. Dimana peneliti saat pengambilan data yang diukur secara mendalam yaitu dengan memberikan asuhan massage perineum pada ibu bersalin kala II.

Sampel yang berjumlah 3 pasien: ibu bersalin kala II, ibu bersalin anak ketiga dan taksiran berat janin antara 2500-3000 gram. Pengambilan data dilakukan mulai tanggal 2 Januari sampai tanggal 25 Januari 2019 di RSUD Cilacap.

Instrumen penelitian studi kasus adalah dengan memahami model analisis case study research, peneliti harus menguasai partisipan yang diteliti, melalui prosedur asuhan massage perineum dan pada bagian akhir adalah melakukan evaluasi.

\section{Hasil dan Pembahasan}

Berdasarkan pengkajian dan analisis data yang telah dilakukan pada 3 (tiga) partisipan dengan model asuhan kebidanan massage perineum sebanyak $2 \mathrm{x}$ dapat diperoleh hasil sebagai berikut:

Tabel 1. Data ketebalan perineum sebelum dan sesudah tindakan.

\begin{tabular}{ccccccc}
\multirow{2}{*}{ Nama } & \multicolumn{2}{c}{ Sebelum Tindakan } & \multicolumn{2}{c}{$\begin{array}{c}\text { Sesudah Tindakan } \\
\text { Tahap I }\end{array}$} & \multicolumn{2}{c}{$\begin{array}{c}\text { Sesudah Tindakan } \\
\text { Tahap II }\end{array}$} \\
\cline { 2 - 7 } & Perineum & Ketebalan & Perineum & Ketebalan & Perineum & Ketebalan \\
\hline Ny. $\mathrm{S}_{1}$ & Rigid & $1,8 \mathrm{~cm}$ & Elastis & $1,5 \mathrm{~cm}$ & Menipis & $1,5 \mathrm{~cm}$ \\
\hline Ny. $\mathrm{S}_{2}$ & Rigid & $1,7 \mathrm{~cm}$ & Elastis & $1,5 \mathrm{~cm}$ & Menipis & $1,5 \mathrm{~cm}$ \\
\hline Ny. Y & Rigid & $1,5 \mathrm{~cm}$ & Elastis & $1,1 \mathrm{~cm}$ & Menipis & $1,1 \mathrm{~cm}$ \\
\hline
\end{tabular}

Sumber: Data olahan sendiri

Sebelum dan sesudah dilakukan tindakan massage perineum pada 3 (tiga) partisipan didapatkan hasil keadaan perineum mengalami perubahan, pada $\mathrm{Ny} . \mathrm{S}_{1}$ keadaan perineum rigid dan ketebalan perineum $1,8 \mathrm{~cm}$, pada pemantauan tahap I keadaan perineum elastis dan ketebalan perineum menjadi $1,5 \mathrm{~cm}$, pada pemantauan tahap II keadaan perineum semakin menipis dan ketebalan perineum $1,5 \mathrm{~cm}$.
Sedangkan pada Ny. $\mathrm{S}_{2}$ mengalami perubahan keadaan perineum rigid dan ketebalan 1,7 cm, pada pemantauan tahap I keadaan perineum elastis dan ketebalan perineum menjadi $1,5 \mathrm{~cm}$. Pada pemantauan tahap II keadaan perineum semakin menipis dan ketebalan perineum $1,5 \mathrm{~cm}$. Pada Ny. $\mathrm{Y}$ perubahan ketebalan perineum lebih banyak keadaan perineum rigid dan ketebalan perineum 1,5 cm, pada 
Jurnal Kebidanan Harapan Ibu Pekalongan

pemantauan tahap I keadaan perineum elastis dan ketebalan perineum menjadi $1,1 \mathrm{~cm}$. Sampai pada pemantauan tahap kedua keadaan perineum mengalami penipisan dan ketebalan perineum 1,1 $\mathrm{cm}$.

Tabel 2. Hasil waktu persalinan yang terjadi pada setiap partisipan

\begin{tabular}{cccc}
\hline Partisipan & $\begin{array}{c}\text { Waktu } \\
\text { kala II }\end{array}$ & $\begin{array}{c}\text { Berat Badan } \\
\text { Bayi } \\
\text { (gram) }\end{array}$ & Laserasi \\
\hline Ny.S $_{1}$ & 15 menit & 3000 & Perlukaan kecil \\
\hline Ny.S & 10 menit & 2950 & $\begin{array}{c}\text { Tidak ada } \\
\text { laserasi }\end{array}$ \\
\hline Ny.Y & 20 menit & 2800 & Perlukaan kecil \\
\hline
\end{tabular}

\section{Sumber: Data olahan sendiri}

Berdasarkan hasil pemantauan pada 3 partisipan mengalami percepatan waktu persalinan kala II yang berbeda. Pada Ny. $\mathrm{S}_{1}$ setelah dilakukan massage perineum waktu persalinan kala II berlangsung selama 15 menit dan mengalami perlukaan kecil setelah proses persalinan kala II dengan berat bayi 3000 gram. Sedangkan pada Ny. $\mathrm{S}_{2}$ waktu persalinan kala II berlangsung selama 10 menit dan tidak ada laserasi setelah proses persalinan kala II dengan berat bayi 2950 gram. Serta pada Ny. Y waktu persalinan kala II berlangsung selama 20 menit dan mengalami perlukaan kecil setelah proses persalinan kala II dengan berat bayi 2800 gram.

Berdasarkan hasil pengkajian data yang dilakukan pada 3 (tiga) partisipan ibu bersalin di Ruang Teratai RSUD Cilacap, setelah dilakukan tindakan massage perineum menunjukan bahwa pada 3 (tiga) partisipan didapatkan hasil perineum kaku dan ketebalan perineum mengalami perubahan.

Menurut Cunningham (2013), elastisitas perineum yang tidak adekuat merupakan faktor maternal yang sangat berpengaruh terhadap terjadinya laserasi perineum maupun tindakan episiotomi. Ketika semua otot-otot tersebut menjadi elastis, maka ibu tidak perlu meneran terlalu keras cukup pelan-pelan saja bahkan bila prosesnya lancar laserasi pada perineum tidak terjadi maka tidak perlu dijahit. Hal ini sejalan dengan Mehran (2016), bahwa dengan melakukan gerakan menggosok akan membuat suhu otot meningkat, sehingga meningkatnya produksi ATP atau energi, dimana ATP ini digunakan untuk membantu ion-ion $\mathrm{Ca}++$ dipompa masuk kembali kedalam reticulum sarkoplasma dengan cara transpor aktif, sehingga kerja troponin dan tropomiosin kembali aktif guna menghambat reaksi aktin myosin dalam kata lain, aktin-myosin tidak dalam keadaaan aktif, kemudian otot akan relaksasi (mengendur atau menjadi lentur). ${ }^{[10]}$

Menurut varney (2008), perineum harus segera di evaluasi sebelum waktu persalinan untuk mengetahui panjangnya, ketebalan dan distensibilitasnya. Ketebalan perineum distensibilitasnya yang dimaksud sejalan dengan teori selly (2000), bahwa selama kehamilan perineum berfungsi untuk mempertahankan uterus supaya tidak terjadi prolaps, dalam mempertahankan uterus dibutuhkan ATP atau energi, ATP banyak diproduksi pada metabolisme aerob, asam piruvat masuk ke mitokondria dirubah menjadi karbohidrat dan air. Setiap molekul glukosa mengandung 38 molekul ATP, ketika pasokan oksigen kurang untuk membangun ATP dan metabolisme menjadi anaerob, asam piruvat yang masuk ke mitokondria diubah menjadi asam laktat menyebabkan masalah metabolisme dan terjadi penyusutan antar sel otot perineum sehingga, perineum menjadi rigid. ${ }^{[12][13]}$

Sedangkan hasil penelitian yang dilakukan oleh peneliti pada 3 partisipan, setelah dilakukan asuhan massage perineum lebih cepat mengalami percepatan persalinan 
kala II untuk yang pertama kali dibandingkan dengan penelitian sebelumnya. Dari hasil penelitian partisipan pertama mengalami percepatan persalinan kala II 15 menit, partisipan kedua 10 menit, dan partisipan ketiga 20 menit. Hal ini membuktikan bahwa massage perineum bermanfaat untuk percepatan persalinan kala II.

Hasil penelitian yang dilakukan Nelly Indrasari (2014) ditemukan rata-rata lama kala II pada ibu bersalin rata-rata waktu yang di butuhkan pada multi adalah 26,02 menit. Massage perineum dapat mempercepat persalinan kala II dengan cara melancarkan aliran darah di daerah perineum dan vagina, serta aliran hormon yang membantu melemaskan otot-otot dasar panggul sehingga proses persalinan kala II jadi lebih mudah. ${ }^{[14]}$

Sejalan dengan teori Varney (2007), bahwa penurunan mencapai kecepatan maksimum penurunan rata-rata nulipara adalah 1,6 sentimeter per jam dan normalnya paling sedikit 1,0 sentimeter per jam. Pada multipara, kecepatan penurunan rata-rata 5,4 sentimeter per jam, dengan kecepatan minimal 2,1 sentimeter per jam. Pada ibu multipara, penurunan kepala janin mendekati pembukaan lengkap. ${ }^{[12]}$

\section{Kesimpulan}

Berdasarkan hasil pengkajian dan pembahasan asuhan dengan melakukan tindakan massage perineum. Partisipan pertama ketebalan dari rigid $1,8 \mathrm{~cm}$ menjadi menipis $1,5 \mathrm{~cm}$. Partisipan kedua ketebalan dari rigid dari $1,7 \mathrm{~cm}$ menjadi menipis1,5 cm dan partisipan ketiga ketebalan dari rigid $1,5 \mathrm{~cm}$ menjadi menipis $1,1 \mathrm{~cm}$. Peneliti dapat mengambil simpulan bahwa massage perineum efektif untuk percepatan persalinan kala II pada ibu bersalin dengan waktu rata rata 10 menit.
Laserasi bagian perineum pada partisipan pertama dan ketiga tingkat laserasi hanya perlukaan kecil sehingga tidak dijahit. Sedangkan pada partisipan kedua pada bagian perineum tidak mengalami laserasi. Sejalan dengan teori Simkin (2008), bahwa massage perineum sangat efektif karena peningkatan elastisitas perineum akan mencegah kejadian robekan perineum. ${ }^{[14],[15],[16]}$

\section{Daftar Pustaka}

[1] Affandi, Biran. 2008. Asuhan Persalinan Normal Dan Inisiasi Menyusui Dini. Jakarta: Jaringan Nasional Pelatihan Klinik. Diakses tanggal 02 Oktober 2018 http://www.journal.stikeseub. ac.id

[2] Badan Penelitian dan Pengembangan Kesehatan Kementerian Kesehatan RI. 2013. Riset Kesehatan Dasar 2013. Jakarta.

[3] Sumarah, widyastuti Y., \& Wiyati N. 2009. Perawatan Ibu Bersalin (Asuhan Kebidanan Pada Ibu Bersalin). Yogyakarta: Fitramaya.

[4] Oxorn. H., Forte. W. R. 2010. IlmuKebidanan Patologi dan Fisiologi Persalinan. Yogyakarta: Yayasan Essentia Medica (YEM).

[5] Profil Kesehatan Provinsi Jawa Tengah Tahun 2016. Diakses tanggal 05 November 2018 http://www.depkes.go.id/reso urces/download/profil/PROF IL_KES_PROVINSI_2016/1 3_Jateng_2016.pdf

[6] Saifudin, Abdul Bari. 2010. Ilmu Kebidanan Sarwono Prawiroharjo. Jakarta: Tridasa Printer.

[7] Indrasari, Nelly. 2014. Perbedaan Lama Persalinan Kala Ii Pada Posisi Miring 
Dan Posisi Setengah Duduk. Diakses tanggal 10 Oktober 2018

https://ejurnal.poltekkes-

tjk.ac.id/index.php/JKEP/arti cle/view/321

[8] Bahiyatun. 2011. Buku Ajar Kebidanan Asuhan Nifas Normal. Jakarta: EGC.

[9] Indivara. 2009. Panduan senam hamil. Jakarta : Rineka Cipta.

[10] Cunningham, F. (2013). Obstetri Williams. (21st ed.). (Vols. 1). (Profitasari,Penerjemah.) Jakarta: ECG

[11] Mahena

[12] Varney,H., 2007. Buku Ajar Asuhan Kebidanan Edisi 4. Jakarta;EGC

[13] Varney.2008. Buku Ajar Asuhan Kebidanan. Jakarta : EGC
[14] Nelly Indrasari. 2014. Perbedaan Lama Persalinan Kala II Pada Posisi Miring dan Posisi Setengah Duduk. Jurnal Keperawatan. Vol X, No. 1, April 2014.

[15] Simkins, Penny;Ancheta, Ruth, 2005, Buku Saku Persalinan, EGC, Jakarta.

[16] Hestianingrum, Panca Ratna Djarot, H. S., \& Purwanti, I. A. (2010). Hubungan Tingkat Kecukupan Protein Dengan Lama Penyembuhan Luka Perineum Ibu Nifas Di Wilayah Kerja Puskesmas Tawangharjo Kabupaten Grobogan. Universitas Muhammadiyah Semarang. 